\title{
TISSUE AND PLASMA CONCENTRATIONS OF ANTIBIOTIC DURING CARDIAC SURGERY WITH CARDIOPULMONARY BYPASS - MICRODIALYSIS STUDY
}

\author{
Marek Pojara*, Jiri Mandak, Jana Malakova ${ }^{\mathrm{b}}$, Iveta Jokesova ${ }^{\mathrm{b}}$
}

\author{
${ }^{a}$ Department of Cardiac Surgery, Charles University in Prague, Faculty of Medicine and University Hospital in Hradec \\ Králové, Czech Republic \\ ${ }^{b}$ Institute of Clinical Biochemistry and Diagnostics, Charles University in Prague, Faculty of Medicine and University \\ Hospital in Hradec Králové, Czech Republic \\ e-mail:marek.pojar@centrum.cz
}

Received: February 20, 2008; Accepted (with revisions): May 15, 2008

Key words: Microdialysis/Antibiotic concentrations/Target site/Cardiopulmonary bypass/Cardiac surgery

Aim: Surgical-site infections are very serious complications of cardiac operations. Use of cardiopulmonary bypass (CPB) is associated with profound physiological changes, which affects the pharmacokinetic behaviour of prophylactic antibiotics. The aim of this study was to monitor tissue concentrations of cefuroxime in peripheral tissue (skeletal muscle) during cardiac surgery using CPB by means of a microdialysis.

Methods: Eleven adult patients operated on using CPB were included in the study. Cefuroxime was the prophylactic antibiotic and study drug given. Microdialysis was performed by probe CMA 60 inserted into the patient's left deltoid muscle. Samples of dialysates were collected at intervals: before CPB, each 30 minutes of CPB and at the end of CPB. Samples of blood were collected at intervals: incision, start of CPB, each 30 minutes of CPB, at the end of $\mathrm{CPB}$ and at the end of surgery.

Results: The mean ( \pm S.D.) concentrations of cefuroxime in peripheral tissue were 105.4 $\pm 41.1,81.7 \pm 32.8,74.6 \pm 26.0$, $70.4 \pm 34.7,60.5 \pm 27.2,138.0 \pm 42.6\left(\mathrm{mg} \mathrm{l}^{-1}\right)$. Total plasma concentrations of cefuroxime were $154.4 \pm 41.6,73.3 \pm 20.7$, $67.1 \pm 20.4,59.2 \pm 21.0,49.0 \pm 16.4,110.9 \pm 33.6\left(\mathrm{mg} \mathrm{l}^{-1}\right)$ and concentrations of free plasma fraction were 110.7 \pm 37.1 , $62.2 \pm 18.8,58.9 \pm 18.6,48.4 \pm 16.6,41.7 \pm 15.6,97.6 \pm 28.6\left(\mathrm{mg} \mathrm{l}^{-1}\right)$. The plasma and tissue concentrations exceed throughout the operation time the minimum inhibitory concentration for most common suspected pathogens in cardiac surgery.

Conclusions: Results show that CPB can modify the time course of cefuroxime tissue and plasma concentrations. Microdialysis is suitable for antibiotic tissue measurement in cardiac surgery.

\section{INTRODUCTION}

Wound and mediastinal infections along with postoperative endocarditis are very serious complications of cardio surgical operations with life-threatening consequences for the patient. The incidence of sternal infection after cardiac operations ranges from $0.9 \%$ to $20 \%$ in various studies and the incidence of mediastinitis is $1-2 \%$ in most reports ${ }^{1}$. The mortality rate for patients with deep sternal infections ranges from 9.8 to $14 \%^{2}$. These infectious complications require repeated surgical intervention accompanied by aggressive pharmacological treatment.

To reduce the risk of such sequellae, for several years, prophylactic use has been made of intravenous antibiotics in patients undergoing cardiac surgery ${ }^{3}$. The aim of the prophylaxis is to achieve levels of the free plasma and target site concentrations of antibiotic (ATB) in soft tissue, which exceed the minimum inhibitory concentration (MIC) for the most common suspected pathogens and to maintain these concentrations throughout the operation. Common suspected pathogens are usually Grampositive cocci, Staphylococcus aureus and Staphylococcus epidermidis (coagulase-negative staphylococcus). Cephalosporins (beta-lactam antibiotics) are frequently used in cardiac surgery for their broad spectrum of activity and low degrees of toxicity ${ }^{4,5}$.

The question is whether antibiotic prophylaxis currently practiced in cardiac surgery provides sufficient protection during cardiac surgery and in the postoperative period. Studies on antibiotic prophylaxis and the use of extra-corporeal circulation are based on evaluation of antibiotic concentrations in serum. Recent studies have indicated that target site concentrations of antibiotics in soft tissues may be inadequate and subinhibitory, despite adequate plasma concentrations ${ }^{6,7}$. Suboptimal, subinhibitory, target site concentration of antibiotic may explain antibiotic prophylaxis failure despite recorded in vitro susceptibility to suspected microorganism and adequate plasma concentrations.

The use of cardiopulmonary bypass (CPB) is associated with profound physiological changes and altered protein binding. CPB can thus modify the distribution of antibiotics ${ }^{8,9}$. As a result there can be inadequate antibiotic concentration with a higher risk of infectious complications.

The present study was designed to measure unbound (microbiologically active) concentrations of $\beta$-lactam antibiotics in the interstitial space fluid of soft tissue during 
surgery with $\mathrm{CPB}$ and to relate these concentrations to corresponding plasma levels.

A new method that allows continuous measurement of unbound antibiotic concentration in the peripheral space of the tissue is microdialysis. We measured interstitial concentrations of cefuroxime by means of in vivo microdialysis.

\section{MATERIAL AND METHODS}

The study was carried out at the Cardiac Surgery Department, University Hospital and Medical Faculty in Hradec Králové, Charles University in Prague. The local ethics committee at the University Hospital in Hradec Králové, in accordance with the Declaration of Helsinki, approved the study. All subjects were given a detailed description of the study, and their written informed consent was obtained.

\section{Patients}

Eleven patients ( 9 male, 2 female) were included in the study. All patients underwent elective cardiac surgery procedure in CPB. Patients were excluded from the study if they had received any treatment with any antibiotics within the 14 days prior to the start of the study, or had allergic or hypersensitive reaction to $\beta$-lactam antibiotics in their history. Patients with an active infection or renal failure, and patients operated on as emergencies were also excluded.

\section{Cardiopulmonary bypass and surgical procedure}

The anaesthetic management, CPB and surgical procedures were standardized. Food and fluid intake was discontinued at midnight on the day preceding surgery. Anaesthesia was induced with intravenous thiopental or midazolam and sufentanyl, muscle relaxation with cisatracurium. Anaesthesia was maintained by infusion of cisatracurium, sufentanyl and propofol and dose changes were made to keep the patient adequately anaesthetized and hemodynamically stable. Isoflurane was added in oxygen.

Standard adult extracorporeal tubing set was used incorporating a $40 \mu \mathrm{m}$ arterial filter. The extracorporeal circuit consisted of a hollow fibre membrane oxygenator with integral heat exchanger (D903 AVANT, Dideco, Mirandola, Italy) and a roller pump with non-pulsatile flow (Stöckert S3, Sorin Group, Munich, Germany). The oxygenator and tubing were primed with a mixture of crystaloid and coloid solutions. No antibiotics were added to the prime solution. Anticoagulation was induced before CBP with heparin $\left(2.5 \mathrm{mg} \mathrm{kg}^{-1}\right)$, and the activated clotting time (ACT) was monitored. Additional doses of heparin were given to maintain ACT time over 480 seconds. After $\mathrm{CPB}$, heparin was neutralized with protamine sulphate at a 1:1 ratio. After median sternotomy and pericardotomy standard aortic cannula and two-stage venous cannula (inserted into the inferior vena cava through the right atrium) were used. CPB involved normotermia and calculated blood flow of $2.41 \mathrm{~m}^{-2} \mathrm{~min}^{-1}$. Mean arterial pressure
(MAP) during CPB was maintained at 50 to $75 \mathrm{mmHg}$, hematocrit was above $20 \%$. The acid base status was maintained using the alpha-stat perfusion strategy. After the aorta had been cross-clamped, cardiac arrest was initiated by the antegrade infusion of cold crystalloid potassium cardioplegia (St. Thomas solution, Ardeapharma, Ševětín, Czech Republic), repeated every 20 minutes and topical cooling for myocardial protection was employed.

\section{Measurement of interstitial antibiotic concentration, microdialysis}

Microdialysis is a minimally invasive technique based on the sampling of unbound molecules from the extracellular space (interstitial fluid) of tissue by means of a semipermeable membrane at the tip of a microdialysis probe. The basic principle is to mimic the function of a capillary blood vessel. The probe is constantly perfused with physiological solution at a constant low flow rate. Substances present in the interstitial fluid surrounding the microdialysis probe at concentration $\left(\mathrm{c}_{\text {tissue }}\right)$ diffuse through the membrane into the probe, resulting in a concentration $\left(\mathrm{c}_{\text {dialysate }}\right)$ in the perfusion medium. Samples of the microdialysates are collected and analysed.

For most analytes the equilibrium between interstitium and perfusion medium is incomplete, and therefore $\mathrm{c}_{\text {tissue }}$ is greater than $\mathrm{c}_{\text {dialysate }}$. For in vivo quantitative measurement the microdialysis probe needs to be calibrated. The calibration factor by which the concentrations are interrelated is termed „recovery“ (recovery $(\%)=\mathrm{c}_{\text {dialysate }}$ $\mathrm{X} \mathrm{c}_{\text {tissue }}^{-1} \mathrm{x} \mathrm{100)}$.

To obtain an absolute drug concentration in the interstitial fluid from the concentration measured in the dialysate, in vivo recovery was assessed in each experiment by the retrodialysis method. The principle of this method relies on the fact that the diffusion process is quantitatively equal in both directions through the semipermeable membrane. Cefuroxime was added to the perfusion medium (Ringer's solution, Braun Melsungen AG, Melsungen, Germany: $\mathrm{Na}^{+} 147 \mathrm{mmol} \mathrm{l}^{-1}, \mathrm{~K}^{+} 4 \mathrm{mmol} \mathrm{l}^{-1}$, $\mathrm{Ca}^{+2} 2.25 \mathrm{mmol} \mathrm{l}^{-1}, \mathrm{Cl}^{-1} 156 \mathrm{mmol} \mathrm{l}^{-1}, 309 \mathrm{mosmol} \mathrm{l}^{-1}$ ) and its rate of disappearance through the membrane was taken as the in vivo recovery ${ }^{6,10,11}$. The in vivo recovery value was calculated as: recovery $(\%)=100-(100 \mathrm{x}$ analyte concentration $_{\text {dialysate }} \mathrm{X}$ analyte concentration perfusate $\left.^{-1}\right)$.

\section{Antibiotic prophylaxis regimens and study drug}

Cefuroxime (Axetine, Medochemie Ltd., Limassol, Cyprus), second generation cephalosporin, was used as a prophylactic, study, antibiotic ( $1.5 \mathrm{~g}$ cefuroxime in $20 \mathrm{ml}$ $\mathrm{NaCl}$ administered as a bolus injection through a central vein catheter). Antibiotic prophylaxis was given in accordance with the standard protocol of our cardiac centre. The first dose was administered (cefuroxime $3.0 \mathrm{~g}$ ) at the time of anaesthesia induction, the second dose $(1.5 \mathrm{~g})$ at the same time as protamine infusion after removing the aortic perfusion cannula (end of CPB), the third dose $(1.5 \mathrm{~g})$ after 8 hours (in case of revascularisation procedures), and every $8^{\text {th }}$ hour up to 48 hours postoperatively (procedures on the valves). 


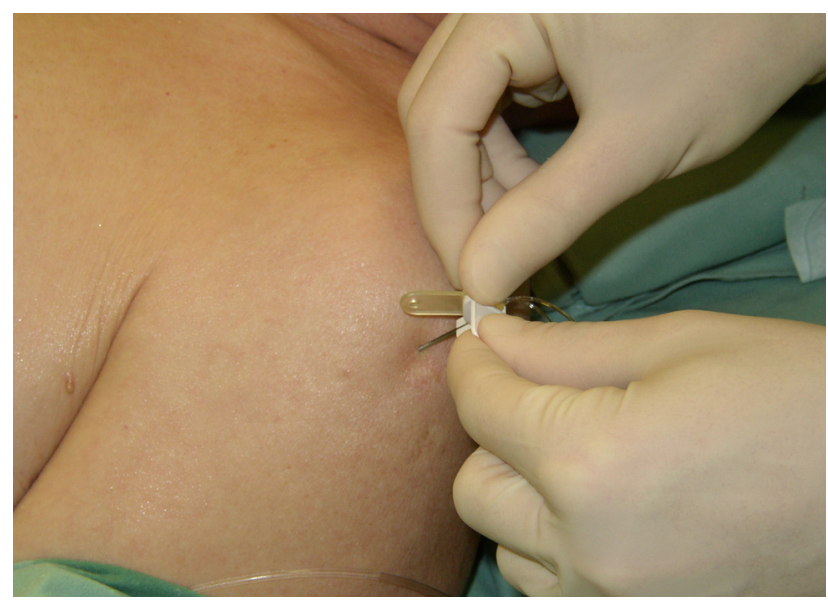

Fig. 1. Microdialysis catheter is just inserted into the left deltoid muscle.

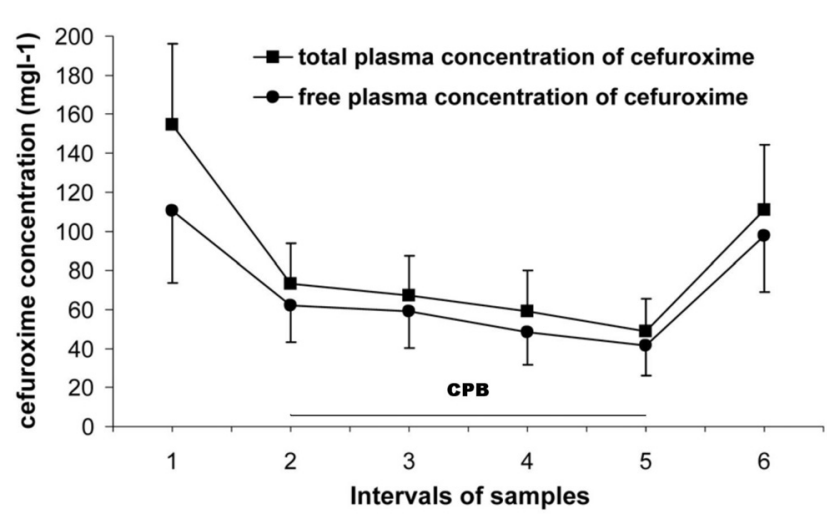

Fig. 3. Plasma concentrations of cefuroxime - total and free (unbound) fraction $\left(\mathrm{mg} \mathrm{l}^{-1}\right)$. Mean \pm S.D. CPB- cardiopulmonary bypass.

\section{Study protocol}

The patients remained in a supine position throughout the study period. Before the operation procedure one commercially available microdialysis probe (CMA 60; CMA Microdialysis AB, Solna, Sweden) with a molecular weight cut-off of 20,000 Dalton and a polyamide membrane length of $30 \mathrm{~mm}(0.6 \mathrm{~mm}$ in diameter $)$ was inserted under sterile conditions into the skeletal muscle tissue (left deltoid muscle) without prior anaesthesia (Fig. 1).

The microdialysis probe was connected and constantly perfused with Ringer's solution at a constant flow rate of $0.1 \mathrm{ml} \mathrm{h}^{-1}$ by means of a precision pump (Pilote A2 IS2, Fresenius Vial, Le Grand Chemin, Brezins, France). Prior to the systemic administration of the study drug, after a 30-min. baseline sampling period, in vivo probe calibration was done. As described previously, the microdialysis probe was flushed with a solution of the drug for 30 minutes to obtain individual the in vivo recovery value by means of the retrodialysis method. After a sufficient washout period for the system with Ringer's solution, the first dose of cefuroxime ( $3.0 \mathrm{~g})$ was administered in the period of anaesthesia induction.

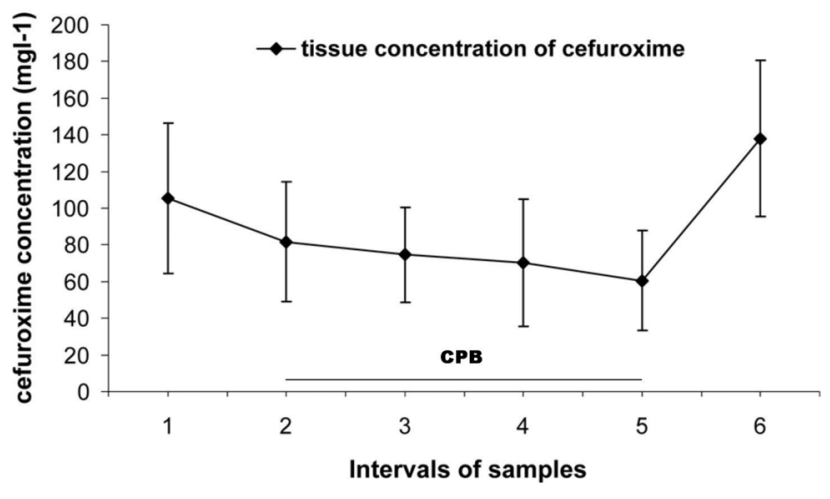

Fig. 2. Cefuroxime tissue concentrations $\left(\mathrm{mg}^{-1}\right)$. Mean \pm S.D. CPB- cardiopulmonary bypass.

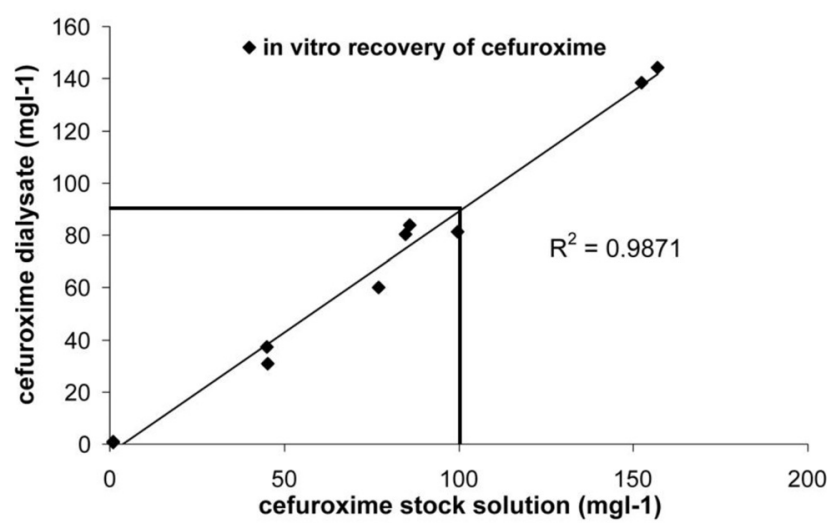

Fig. 4. In vitro calibration of the microdialysis probe for cefuroxime. Cefuroxime concentrations were measured in the dialysate and in the surrounding medium. The linear regression indicates a consistent relationship between the concentration in surrounding solution and in the dialysate over a wide concentration range. The vertical and horizontal lines illustrate the method for determining the in vitro recovery, which was $89 \%$ for cefuroxime.

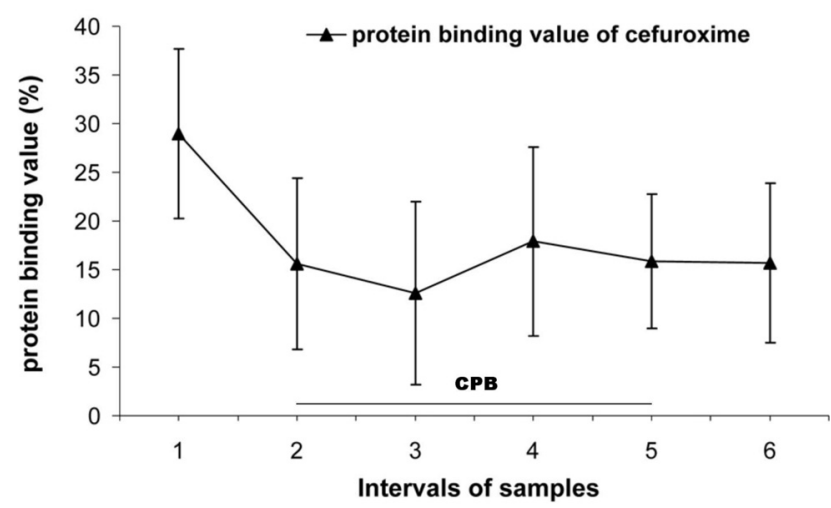

Fig. 5. Changes of the protein binding value during cardiac surgery with cardiopulmonary bypass. Mean \pm S.D. CPB-cardiopulmonary bypass. 
Sampling of microdialysates at 30-min. intervals was performed at defined time intervals throughout the operation procedure (1- skin incision, before CPB, 2-5 - during CPB, 6 - wound closure, after CPB, Fig. 2). Blood samples $(2 \mathrm{ml})$ from the arterial catheter were sampled during the operation procedure (1- skin incision, 2- beginning of CPB, 3-5 - every 30-min. during CPB, 6- end of the operation, wound closure, Fig. 3). After the microdialysis procedure, the probe was removed. The lag time due to the dead volume between microdialysis membrane and the point of dialysate collection was taken into account.

Microdialysis samples were stored at $-80{ }^{\circ} \mathrm{C}$ until analysis. Blood samples were collected in tubes containing ethylenediaminetetraacetic acid (EDTA) as an anticoagulant, centrifuged and plasma samples were stored at $-80{ }^{\circ} \mathrm{C}$ until analysis.

\section{Probe in vitro recovery calculation}

To obtain basic data on the microdialysis probe function apropos the transport of cefuroxime via its semipermeable membrane, probe recovery was determined in vitro. The probe was immersed in $100 \mathrm{ml}$ of cefuroxime solution (different concentrations of cefuroxime) at a constant temperature $\left(25^{\circ} \mathrm{C}\right)$ and perfused with Ringer's solution at a flow rate of $0.1 \mathrm{ml} \mathrm{h}^{-1}$. Analytes were measured in the dialysate, and the results were plotted against the concentrations in the surrounding medium (Fig. 4).

\section{Drug analysis}

Standard procedures were used for measuring drug concentrations in plasma (free and total) and in the microdialysate. High-performance liquid chromatography (HPLC) with UV photodiode-array detection (PDA) for determination of cefuroxime in plasma samples and in samples from microdialysis was developed and validated.
The detection of cefuroxime was performed on a PDA detector at $254 \mathrm{~nm}$. The procedure in samples from in vivo microdialysis included only the addition of the internal standard cefoxitin before HPLC separation. The unbound cefuroxime fraction in plasma was obtained using ultrafiltration method on column Microcon YM 10 (Amicon).

\section{Calculation and data analysis}

As described above, drug equilibration between interstitial fluid and perfusion solution is incomplete. Therefore the concentrations of study drug, measured in microdialysate samples, were corrected by the following equation to obtain free drug concentration in the extracellular space in the soft tissue: $\mathrm{c}_{\text {extracellular }}=100 \mathrm{x}\left(\mathrm{c}_{\text {dialysate }} \mathrm{x}\right.$ in vivo recovery $\left.(\%)^{-1}\right)$.

Demographic and perioperative parameters were analysed by descriptive methods (mean \pm standard deviation S.D.); drug concentrations are expressed as mean \pm S.D.

\section{RESULTS}

The pre and perioperative characteristics of the eleven patients are recorded in table 1 . Seven patients underwent revascularization and in four patients the valve replacement procedure was used. None suffered from postoperative surgical site infection.

Initial concentrations, both plasma and tissue concentrations, were gradually decreased after the start of CPB and lasted until CPB ended. Further increase in the values could be seen after the application of the second dose of antibiotic at the time of protamine administration (sampling interval 6). The time course of the free cefuroxime concentrations in the interstitial space for the

Table 1. Preoperative and perioperative characteristics.

\begin{tabular}{|c|c|c|c|}
\hline & Mean \pm S.D. & Min. & Max. \\
\hline Age $(y)$ & $65.5 \pm 11.0$ & 44 & 81 \\
\hline Weight $(\mathrm{kg})$ & $75.1 \pm 12.2$ & 50 & 91 \\
\hline Height $(\mathrm{cm})$ & $171.7 \pm 9.8$ & 153 & 181 \\
\hline Body mass index & $25.4 \pm 3.1$ & 19.5 & 29.1 \\
\hline $1^{\text {st }}$ dose of ATB $\left(\mathrm{mg} \mathrm{kg}^{-1}\right)$ & $41.1 \pm 7.8$ & 33.0 & 60.0 \\
\hline $1^{\text {st }}$ dose of ATB $\left(\mathrm{mg} \mathrm{cm}^{-2}\right)$ & $1631.2 \pm 188.6$ & 1415.1 & 2013.4 \\
\hline Operation time $(\min )$ & $189.1 \pm 39.2$ & 130 & 245 \\
\hline CPB time ( $\min )$ & $87.8 \pm 21.9$ & 53 & 132 \\
\hline Prime volume of CPB (ml) & $1538.2 \pm 220.6$ & 1200 & 1950 \\
\hline Preoperative serum creatinine $\left(\mu \mathrm{mol} \mathrm{1}{ }^{-1}\right)$ & $101.5 \pm 21.2$ & 77 & 143 \\
\hline Preoperative serum urea $\left(\mathrm{mmol} \mathrm{l}^{-1}\right)$ & $5.6 \pm 1.8$ & 2.8 & 8.8 \\
\hline
\end{tabular}

ATB - antibiotic; CPB - cardiopulmonary bypass; S.D. - standard deviation 
skeletal muscle during cardiac surgery with CPB is shown in Fig. 2. The mean concentration-versus-time profile (total and free concentration) of cefuroxime in plasma is depicted in Fig. 3.

The values of cefuroxime in plasma and in the interstitial fluid exceeded the "MICs", the minimum inhibitory concentrations (Gram-positive bacteria $2 \mathrm{mg} \mathrm{l}^{-1}$, Gramnegative bacteria $4 \mathrm{mg} \mathrm{l}^{-1}$ ), throughout the course of the cardiac surgery. Even after 120 minutes of CPB (in three cases) the levels were sufficient and higher than recommended inhibitory concentrations.

The results of the in vitro probe recovery study are depicted in Figure 4. There was a linear correlation between cefuroxime concentrations in the dialysate and surrounding medium over a wide concentration range.

The protein binding values of cefuroxime were calculated from total and free plasma concentrations. The mean protein binding fraction before the institution of the bypass was $29.0 \%$ and decreased to $15.6 \%$ after the initiation of CPB and remained at this level throughout the bypass period (Fig. 5).

\section{DISCUSSION}

The present study is the first to evaluate tissue concentrations of prophylactically administered antibiotics during cardiac surgery with CPB by means of a bioanalytical sampling technique, interstitial microdialysis. We determined cefuroxime concentrations in the interstitial fluid of the peripheral muscle and in the plasma.

Antibiotic prophylaxis against bacterial infections has become the standard method for protecting patients during cardiac surgery and in the early postoperative period. The prophylaxis aims to achieve plasma and, above all, tissue levels of antibiotic, which at the time of the operation exceed the minimum inhibitory concentration for the pathogens. The number of resistant microorganisms is increasing, particularly the beta-lactamase producing gram-negative organisms, which have the ability to destroy many penicillins and cephalosporins. The reason for development of resistance may be the long-term application of antibiotics and ineffective dose regimens. Clinical and experimental studies have shown that for optimal antibiotic effect it is necessary to achieve high concentrations in plasma and tissues during the operative procedure, which is the time of maximal contamination ${ }^{3}$. In cardiac surgery it is mainly in the period of clot forming after the administration of the protamine and in the phase of the wound closure.

Antibiotics are substances, which can be partially bound to plasma proteins or to the blood cells, or they may diffuse into the blood cells. A portion remains unbound. Free antibiotic concentrations in the interstitial fluid at the target site are responsible for the antibacterial effect and may be more relevant in predicting therapeutic efficiency than plasma concentrations ${ }^{12,13}$. As known, in the case of soft tissue infections (wound infections) bacteria are localized in the fluid of the interstitial space. In order to achieve a prophylactic effect of an antibiotic, the decisive factor is the concentration of the antibiotic in the extracellular space of the soft tissue. An insufficient level of the antibiotic in the target site may be thus one of the reasons for the anti-infectious therapy failure and development of drug resistance. Several papers have presented the results of microdialysis studies on antibiotic concentrations in the soft tissue. Brunner and colleagues ${ }^{10}$, Joukhadar et al. ${ }^{14}$ and Zeitlinger et al.${ }^{15}$ described altered or insufficient (subinhibitory) concentrations of antibiotics in the tissue in different conditions and tissues. However, none of them deals with antibiotics determination in the peripheral tissue during a cardiosurgical operation with extracorporeal circulation.

The use of CPB is associated with profound physiological changes. Haemodilution, hypothermia, redistribution of blood flow in the peripheral tissue, isolation of the lungs from the circulation, sequestration in the CPB equipment, decreased renal function, diminished protein binding, reduced clearance, changes in volume of distribution, the activation of the systemic inflammatory reaction are factors that may alter the pharmacokinetic behaviour of antibiotics ${ }^{16-18}$.

In the past various methods were developed to quantify the penetration of antibiotics into soft tissue, but major disadvantages of the these methods (skin blister fluid method, biopsy and the tissue homogenisation, imaging procedures such as a positron emission tomography or magnetic resonance imaging) are limitations for tissue pharmacokinetic studies as well as inability to discriminate between free and bound fractions ${ }^{19,20}$.

In the present study, we used in vivo microdialysis measurement of antibiotic tissue concentrations during the cardiac operation. This method is a new tool for monitoring free drug concentrations (e.g. an antibiotic) in the peripheral tissue directly and continuously. We selected the deltoid muscle as a typical peripheral tissue for insertion of the catheter. This typical skeletal, peripheral muscle is easily accessible and avoids disturbing the sterile conditions (for handling by microvials) throughout the course of the cardiac surgery. Despite the probe being in situ for up to approximately 8 hours, no complications or side effects with the microdialysis were found.

As a prophylaxis, and study drug, we used cefuroxime, because cephalosporins are frequently prescribed for prophylaxis in cardiac surgery ${ }^{21-23}$. The dosing schedules for the cephalosporins (cefuroxime) administration as recommended by the manufacture's are of general validity and can serve as a basis for prophylactic administration in general surgical interventions. However, the dosing (amount and intervals) of prophylactically administered antibiotics in cardiac surgery operations with the use of extracorporeal circulation is not available. Guidelines also vary among the cardiac surgery centres. The differences in dosing regimen are in the duration (single dose regimen versus multiple-dose application prolonged up to 48 hours postoperatively), in the timing of the first and the second administered dose or the amount of the doses ${ }^{17,24,25}$. In this study we tried to evaluate our antibiotic prophylaxis regimen with respect to plasma and especially tissue concentrations. 
The results of this pilot microdialysis study showed dynamic changes in the concentrations of cefuroxime that depend on the phase of the surgery using cardiopulmonary bypass (Figs. 2, 3). We found that muscle concentrations of cefuroxime after the administration reflected plasma concentrations. Both plasma and muscle concentrations of cefuroxime were higher than MICs, the minimum inhibitory concentrations, throughout the course of the surgery. Supported by our data, the practice of $3 \mathrm{~g}$ of cefuroxime administration with anaesthesia induction and $1.5 \mathrm{~g}$ of cefuroxime after CPB provides effective antibacterial concentrations in plasma and skeletal tissue during cardiac surgery with cardiopulmonary bypass. From our data, it seems that administration of the second dose after the end of the CPB is not necessary. However, we recommend the second dose of antibiotic with protamine infusion in order to obtain maximum antibiotic concentration in newly formed blood clots.

Higher concentrations of cefuroxime in the skeletal muscle during the $\mathrm{CPB}$ than plasma concentrations were found in this study. One explanation could be profound physiological changes during CPB. These are closely associated with haemodilution, changes in capillary integrity and a shift of intravascular volume to the extravascular space. Further, the changes in protein binding, which we have noted (Fig. 5), could explain these differences. The decrease in protein binding upon initiation of the bypass could result in potentionally greater transfer of antibiotic to the tissue. In addition, decreased clearance and enhanced volume of distribution for the cephalosporins have been described ${ }^{26,27}$.

From a practical point of view, we used a standard dose of cefuroxime for each patient regardless of bodyweight. The calculated dose of the cefuroxime ranged from 33.0 to $60.0 \mathrm{mg} \mathrm{kg}^{-1}$ (the first dose). We found no simple correlation between the plasma or tissue concentrations and dose, body-weight, body mass index, body surface area or priming volume of the CPB.

Evaluation of the subcutaneous interstitial concentrations of the suprasternal region, near to the incision, is the next step to improve the prophylaxis regimen. This is the typical region for surgical site infections in cardiac surgery, with insufficient blood perfusion of the subcutis.

\section{CONCLUSIONS}

In conclusion, interstitial microdialysis proved to be an excellent method for monitoring unbound substances in peripheral tissue and it promises to lead to greater knowledge on the distribution of drugs in target tissues during surgery.

In this study, the decrease in drug concentrations occurred at the start of CPB and lasted until the end of CPB. The increase in plasma concentrations corresponded with the second dose of drug after $\mathrm{CPB}$. The distribution was influenced by changes during CPB such as haemodilution, alterations in tissue perfusion, capillary fluid pressure and inconstant protein-binding values.

\section{ACKNOWLEDGMENTS}

This study was supported by the Research Project MZO 00179906, Czech Republic.

\section{REFERENCES}

1. Tegnell A, Arén C, Öhman L. Coagulase-negative staphylococci and sternal infections after cardiac operation. Ann Thorac Surg 2000; 69:1104-09.

2. Ridderstolpe L, Gill H, Granfeldt H, Ahlfeldt H, Rutberg H. Superficial and deep sternal wound complications: incidence, risk factors and mortality. Eur J Cardiothorac Surg 2001; 20:1168-75.

3. Kriaras I, Michalopoulos A, Turina M, Geroulanos S. Evolution of antimicrobial prophylaxis in cardiovascular surgery. Eur J Cardiothorac Surg 2000; 18:440-46.

4. Curtis JJ, Boley TM, Walls JT, Hamory B, Schmaltz RA. Randomized, prospective comparison of first- and second-generation cephalosporins as infection prophylaxis for cardiac surgery. Am J Surg 1993; 166:734-37.

5. Townsend TR, Reitz BA, Bilker WB, Bartlett JG. Clinical trial of cefamandole, cefazolin, and cefuroxime for antibiotic prophylaxis in cardiac operations. J Thorac Cardiovasc Surg 1993; 106:66470.

6. Bellmann R, Kuchling G, Dehghanyar P, Zeitlinger M, Minar E, Mayer BX et al. Tissue pharmacokinetics of levofloxacin in human soft tissue infections. Br J Clin Pharmacol 2004; 57:563-68.

7. Tomaselli F, Dittrich P, Maier A, Woltsche M, Matzi V, Pinter J et al. Penetration of piperacillin and tazobactam into pneumonic human lung tissue measured by in vivo microdialysis. Br J Clin Pharmacol 2003; 55:620-24.

8. Adrianzén Vargas MR, Danton MH, Javaid SM, Gray J, Tobin C, Brawn WJ et al. Pharmacokinetics of intravenous flucloxacillin and amoxicillin in neonatal and infant cardiopulmonary bypass surgery. Eur J Cardiothorac Surg 2004; 25:256-60.

9. Pryka RD, Rodvold KA, Ting W, Levitsky S, Frost RW, Lettieri JT. Effects of cardiopulmonary bypass surgery on intravenous ciprofloxacin disposition. Antimicrob Agents Chemother 1993; 37:2106-11.

10. Brunner M, Pernerstorfer T, Mayer BX, Eichler HG, Müller M. Surgery and intensive care procedures affect the target site distribution of piperacillin. Crit Care Med 2000; 28:1754-59.

11. Islinger F, Dehghanyar P, Sauermann R, Bürger C, Kloft C, Müller $\mathrm{M}$ et al. The effect of food on plasma and tissue concentrations of linezolid after multiple doses. Int J Antimicrob Agents 2006; 27:108-12.

12. Joukhadar C, Klein N, Dittrich P, Zeitlinger M, Geppert A, Skhirtladze K et al. Target site penetration of fosfomycin in critically ill patients. J Antimicrob Chemother 2003; 51:1247-52.

13. Liu P, Müller M, Derendorf H. Rational dosing of antibiotics: the use of plasma concentrations versus tissue concentrations. Int J Antimicrob Agents 2002; 19:285-90.

14. Joukhadar C, Klein N, Mayer BX, Kreischitz N, Delle-Karth G, Palkovits $\mathrm{P}$ et al. Plasma and tissue pharmacokinetics of cefpirome in patients with sepsis. Crit Care Med 2002; 30:1478-82.

15. Zeitlinger MA, Dehghanyar P, Mayer BX, Schenk BS, Neckel U, Heinz $\mathrm{G}$ et al. Relevance of soft-tissue penetration by levofloxacin for target site bacterial killing in patients with sepsis. Antimicrob Agents Chemother 2003; 47:3548-53.

16. Lonský V, Mand’ák J, Lonská V, Rozsíval V, Marková D, Kubíček J. Serum oxacilin and cephazolin levels during cardiopulmonary bypass. Perfusion 1992; 7:115-18.

17. Vourisalo S, Pokela R, Syrjala H. Is singl-dose antibiotic prophylaxis sufficient for coronary artery bypass surgery? An analysis of peri- and postoperative serum cefuroxime and vancomycin levels. J Hosp Infect 1997; 37:237-47.

18. Woods M, LeBlanc K, Gersema L. Antibiotic prophylaxis in cardiothoracic surgery: result of a second survey. Hosp Pharm 1990; 25:641-43. 
- microdialysis study

19. Müller M, Haag O, Burgdorff T, Georgopoulos A, Weninger W, Jansen B et al. Characterization of peripheral-compartment kinetics of antibiotics by in vivo microdialysis in humans. Antimicrob Agents Chemother 1996; 40:2703-09.

20. Tomaselli F, Maier A, Matzi V, Smolle-Jüttner FM, Dittrich P. Penetration of meropenem into pneumonic human lung tissue as measured by in vivo microdialysis. Antimicrob Agents Chemother 2004; 48:2228-32.

21. Gentry LO, Zeluff BJ, Cooley DA. Antibiotic prophylaxis in openheart surgery: a comparison of cefamandole, cefuroxime, and cefazolin. Ann Thorac Surg 1988; 46:167-71.

22. Sisto T, Laurikka J, Tarkka MR. Ceftriaxone vs cefuroxime for infection prophylaxis in coronary bypass surgery. Scand J Thorac Cardiovasc Surg 1994; 28:143-48.
23. Slama TG, Sklar SJ, Misinski J, Fess SW. Randomized comparison of cefamandole, cefazolin, and cefuroxime propylaxis in open-heart surgery. Antimicrob Agents Chemother 1986; 29:744-47.

24. Edwards FH, Engelman RM, Houck P, Shahian DM, Bridges CR. The society of thoracic surgeons practice guideline series: antibiotic prophylaxis in cardiac surgery, part I: duration. Ann Thorac Surg 2006; 81:397-404.

25. Kriaras I, Michalopoulos A, Michalis A, Palatianos G, Economopoulos G, Anagnostopoulos $\mathrm{C}$ et al. Antibiotic prophylaxis in cardiac surgery. J Cardiovasc Surg (Torino) 1997; 38:605-10.

26. Buylaert WA, Herrgods LL, Mortier EP, Bogaert MG. Cardiopulmonary bypass and the pharmacokinetics of drugs. An update. Clin Pharmacokinet 1989; 17:10-26.

27. Mets B. The pharmacokinetics of anesthetic drugs and adjuvants during cardiopulmonary bypass. Acta Anaesthesiol Scand 2000; 44:261-73. 